\title{
Editorial: Interactions Between Ozone Pollution and Forest Ecosystems
}

\author{
Elena Paoletti ${ }^{*}$, Zhaozhong Feng ${ }^{2}$, Silvano Fares ${ }^{3}$, Pierre Sicard ${ }^{4}$, \\ Evgenios Agathokleous ${ }^{2}$ and Alessandra De Marco ${ }^{5}$
}

${ }^{1}$ IRET-CNR, Sesto Fiorentino Firenze, Italy, ${ }^{2}$ Key Laboratory of Agrometeorology of Jiangsu Province, Institute of Ecology, School of Applied Meteorology, Nanjing University of Information Science \& Technology (NUIST), Nanjing, China, ${ }^{3}$ National Research Council (CNR), Institute of BioEconomy (IBE), Rome, Italy, ${ }^{4}$ ARGANS, Sophia Antipolis, France, ${ }^{5}$ ENEA, CR Casaccia, Sustainability Department, Rome, Italy

Keywords: tropospheric $\mathrm{O}_{3}$, forests, conference proceedings, editorial, special topic

\section{Editorial on the Research Topic}

Interactions between Ozone Pollution and Forest Ecosystems

\section{INTRODUCTION}

Forests are a key element of landscape, carbon sink, biodiversity conservation, and human well-being. The major air pollutant nowadays affecting forest health and biodiversity worldwide is tropospheric ozone $\left(\mathrm{O}_{3}\right)$ (Li et al., 2017; Feng et al., 2019; Agathokleous et al., 2020). Progress has been achieved by controlling the emission of $\mathrm{O}_{3}$ precursors in some areas of the world (Sicard et al., 2013; Paoletti et al., 2014). However, $\mathrm{O}_{3}$ levels still reach potentially phytotoxic thresholds in many areas (Mills et al., 2018a; Sicard et al., 2020). Major gaps of knowledge in our understanding of $\mathrm{O}_{3}$ and forest interactions exist. In particular, risk assessment, multifactorial responses, detoxification mechanisms, and the role of forest vegetation in cleaning urban air require further investigation (Paoletti et al., 2020).

This Research Topic of Frontiers in Forests and Global Change, Interactions between Ozone Pollution and Forest Ecosystems, presents eight original research articles that span the field of $\mathrm{O}_{3}$ research on forests and give new insights based on novel results, thus providing a basis for further studies and potential reduction of the severity of $\mathrm{O}_{3}$ impacts on forests.

Hoshika et al. developed stomatal-flux and exposure-based critical levels for $\mathrm{O}_{3}$ risk assessment of biomass losses in two larch species (Larix), a genus of high forest value. They found that the critical levels for the larches were smaller than those for other forest tree species, suggesting a relatively high susceptibility of these larches. This research also revealed that the use of stomatal fluxes as the metric of dose resulted in no species-specific differences that were found using an exposure-based metric. Protection of forest productivity from negative impacts of $\mathrm{O}_{3}$ requires species-specific critical levels that may be based on either $\mathrm{O}_{3}$ concentrations or stomatal uptake accumulation over the growing season (Moura et al., 2018). Even though $\mathrm{O}_{3}$ concentrations are more easily available, stomatal uptake, more biologically meaningful, is recommended in spite of the more complex calculation (Emberson et al., 2000; Paoletti and Manning, 2007). Stomatal-flux risk assessment may be carried out at different scales, e.g., leaf (Shang et al., 2017), ecosystem (Fares et al., 2013; Hoshika et al., 2017), regional (Anav et al., 2016; De Marco et al., 2020), or global (Mills et al., 2018b). Savi et al. investigated the relationship between stomatal $\mathrm{O}_{3}$ fluxes and net ecosystem productivity (NEP), measured directly at the ecosystem level in a network of forest experimental sites with the eddy covariance technique, by the means of artificial neural networks. The analysis 
highlighted that $\mathrm{O}_{3}$ effects over NEP are highly non-linear and site-specific. By isolating $\mathrm{O}_{3}$ effects from other covarying environmental factors, negative effect on NEP were found in the order of 1 percent. These low but significant effects were correlated with meteorological variables showing that $\mathrm{O}_{3}$ damage depends on weather conditions.

For a proper risk assessment, it is important to evaluate all environmental factors that may affect the ecosystem responses to $\mathrm{O}_{3}$, such as nutrient (Zhang et al., 2018) and water availability (Hoshika et al., 2018). Hunová et al. evaluated $\mathrm{O}_{3}$ concentrations, ambient NOx concentrations and meteorology in Czech mountain forests over the period 1992-2018. They found that both meteorology and air pollution are highly important in affecting day-to-day variability in $\mathrm{O}_{3}$ concentrations in Czech forests. They applied a generalized additive model with semiparametric (penalized-spline-based) components to properly capture the non-linear responses that are typical of $\mathrm{O}_{3}$ studies (Agathokleous et al., 2019) and are not captured by traditional linear regression approaches. Overall, there is an urgent need of using sophisticated statistical approaches for untangling the effects of $\mathrm{O}_{3}$ from those of the co-occurring environmental factors. Multifactorial experiments will help to clarify the contribution of each factor. Sugai et al. investigated $\mathrm{O}_{3}$ responses of larch in combination with soil salinization, an interaction that represents a potential concern for vegetation in many coastal areas (Calzone et al., 2019), and found that the responses were additive and did not exhibit significant interactive effects. Such additive responses are common in experiments where elevated $\mathrm{O}_{3}$ is combined with other factors (e.g., Carriero et al., 2016; Yuan et al., 2017), and their identification and understanding may help developing a conceptual model of plant response to $\mathrm{O}_{3}$ in a multi-factorial world.

Integrating plant detoxification processes into $\mathrm{O}_{3}$ risk assessment is still a major challenge for $\mathrm{O}_{3}$ research. Dusart et al. reviewed the great diversity of antioxidative systems, scattered in different cellular compartments, that are involved in foliar responses to $\mathrm{O}_{3}$, in particular the Halliwell Asada Foyer cycle and phenolic compounds in cell wall, vacuole and chloroplasts. They pointed out that a better understanding of subcellular localization and transport would allow a more precise identification of the respective contribution of each compartment to the foliar defense system, and recommended more detoxification modeling efforts, similar to Tuzet et al. (2011).

The relevance of urban forests for human well-being and other services is continuously rising, and the selection of plant species that may improve air quality is thus of great interest (Samson et al., 2019). Plants may uptake Volatile Organic Compounds (VOC) emitted by anthropogenic activities. Araya et al. found

\section{REFERENCES}

Agathokleous, E., Belz, R. G., Calatayud, V., De Marco, A., Hoshika, Y., Kitao, M., et al. (2019). Predicting the effect of ozone on vegetation via the linear non-threshold (LNT), threshold and hormetic dose-response models. Sci. Total Environ. 649, 61-74. doi: 10.1016/j.scitotenv.2018.08.264 several anthropogenic VOCs (e.g., toluene, styrene, xylenes, naphthalene, benzenes, and trichloroethene) in the leaves of two tree species in Santiago city (Chile), and Liriodendron tulipifera was more efficient than Platanus $\times$ acerifolia in the $\mathrm{O}_{3}$ uptake. However, plants may also emit biogenic VOCs, e.g., isoprene and monoterpenes, which affect air quality and may contribute to $\mathrm{O}_{3}$ formation (Sicard et al., 2018). Fitzky et al. reviewed the interplay of $\mathrm{O}_{3}$ and urban vegetation shedding light on the complex photochemistry leading to $\mathrm{O}_{3}$ production. BVOCs emitted by vegetation can be considered $\mathrm{O}_{3}$ precursors especially in presence of anthropogenically emitted $\mathrm{NO}_{\mathrm{X}}$. The authors highlight differences along the rural-urban gradient affecting tropospheric $\mathrm{O}_{3}$ concentrations. Grote et al. developed a new modeling approach for estimating abiotic and biotic stressinduced de novo emissions of BVOCs from plants. A function is proposed that describes the production of all stress-induced biogenic VOCs and scales with stress intensity. It is hypothesized that the response delay and the form of the function are specific for the production pathway and valid for stress induced by $\mathrm{O}_{3}$ as well as wounding (herbivory). These results will help including biogenic VOC responses to stressors into modeling.

These articles were presented at the 2nd International Conference on "Ozone and Plant Ecosystems" that was held in Florence (Italy) in 2018. The next conference of this series was planned in 2020 but was postponed to May 2021 due to the COVID-19 pandemic (https://cyprus2021.com/). Interestingly, the lockdown following the pandemic resulted in a drastic improvement of the air quality, especially nitrogen dioxide $\left(\mathrm{NO}_{2}\right)$ levels, in many world areas (Zhang et al., 2020), while $\mathrm{O}_{3}$ levels tended to increase in the cities (Sicard et al., 2020). Ozone is a unique air pollutant due to its high reactivity and the fact that is formed by reactions of precursors, including $\mathrm{NO}_{2}$. This is why controlling $\mathrm{O}_{3}$ pollution has resulted to be a serious challenge and justify why more research is still needed about the Interactions between Ozone Pollution and Forest Ecosystems.

\section{AUTHOR CONTRIBUTIONS}

EP, ZF, SF, PS, EA, and AD contributed to writing this Editorial of the Research Topic on Interactions between Ozone Pollution and Forest Ecosystems that they edited in 2019-2020. All authors contributed to the article and approved the submitted version.

\section{FUNDING}

This work was supported by the projects MOTTLES (LIFE15 ENV/IT/000183) and MITIMPACT (ALCOTRA 2016-2020). 
metrics for ozone risk assessment to European forests. Glob. Chang. Biol. 22, 1608-1627. doi: 10.1111/gcb.13138

Calzone, A., Podda, A., Lorenzini, G., Maserti, B. E., Carrari, E., Deleanu, E., et al. (2019). Cross-talk between physiological and biochemical adjustments by Punica granatum cv. Dente di cavallo mitigates the effects of salinity and ozone stress. Sci. Total Environ. 656, 589-597. doi: 10.1016/j.scitotenv.2018.11.402

Carriero, G., Brunetti, C., Fares, S., Hayes, F., Hoshika, Y., Mills, G., et al. (2016). BVOC responses to realistic nitrogen fertilization and ozone exposure in silver birch. Environ. Pollut. 213, 988-995. doi: 10.1016/j.envpol.2015.12.047

De Marco, A., Anav, A., Sicard, P., Feng, Z., and Paoletti, E. (2020). High spatial resolution ozone risk assessment for Asian forests. Environ. Res. Lett. 15:104095. doi: 10.1088/1748-9326/abb501

Emberson, L. D., Ashmore, M. R., Cambridge, H. M., Simpson, D., and Tuovinen, J.-P. (2000). Modelling stomatal ozone flux across Europe. Environmental Pollution 109, 403-413. doi: 10.1016/S0269-7491(00)00043-9

Fares, S., Matteucci, G., Scarascia Mugnozza, G., Morani, A., Calfapietra, C., Salvatori, E., et al. (2013). Testing of models of stomatal ozone fluxes with field measurements in a mixed Mediterranean forest. Atmos. Environ. 67, 242-251. doi: 10.1016/j.atmosenv.2012.11.007

Feng, Z., De Marco, A., Anav, A., Gualtieri, M., Sicard, P., Tian, H., et al. (2019). Economic losses due to ozone impacts on human health, forest productivity and crop yield across China. Environ. Int. 131:104966. doi: 10.1016/j.envint.2019.104966

Hoshika, Y., Fares, S., Gruening, C., Goded, I., De Marco, A., Sicard, P., et al. (2017). Stomatal conductance models for ozone risk assessment at canopy level in two Mediterranean evergreen forests. Agric. For. Meteorol. 234, 212-221. doi: 10.1016/j.agrformet.2017.01.005

Hoshika, Y., Moura, B. B., and Paoletti, E. (2018). Ozone risk assessment in three oak species as affected by soil water availability. Environ. Sci. Pollut. Res. 25, 8125-8136. doi: 10.1007/s11356-017-9786-7

Li, P., Feng, Z., Catalayud, V., Yuan, X., Xu, Y., and Paoletti, E. (2017). A metaanalysis on growth, physiological, and biochemical responses of woody species to ground-level ozone highlights the role of plant functional types. Plant Cell Environ. 40, 2369-2380. doi: 10.1111/pce.13043

Mills, G., Pleijel, H., Malley, C. S., Sinha, B., Cooper, O. R., Schultz, M. G., et al. (2018a). Tropospheric Ozone Assessment Report: present-day tropospheric ozone distribution and trends relevant to vegetation. Elementa Sci. Anthrop. 6:47. doi: 10.1525/elementa.302

Mills, G., Sharps, K., Simpson, D., Pleijel, H., Broberg, M., Uddling, J., et al. (2018b).Ozone pollution will compromise efforts to increase global wheat production. Glob. Chang. Biol. 24, 3560-3574. doi: 10.1111/gcb. 14157

Moura, B. B., Hoshika, Y., Ribeiro, R. V., and Paoletti, E. (2018). Exposureand flux-based assessment of ozone risk in two sugarcane genotypes. Atmos. Environ. 176, 252-260. doi: 10.1016/j.atmosenv.2017.12.039

Paoletti, E., De Marco, A., Beddows, D. C. S., Harrison, R. M., and Manning, W. J. (2014). Ozone levels in European and USA cities are increasing more than at rural sites, while peak values are decreasing. Environ. Pollut. 192, 295-299. doi: 10.1016/j.envpol.2014.04.040

Paoletti, E., Feng, Z., De Marco, A., Hoshika, Y., Harmens, H., Agathokleous, E., et al. (2020). Challenges, gaps and opportunities in investigating the interactions of ozone pollution and plant ecosystems. Sci. Total Environ. 709:136188. doi: 10.1016/j.scitotenv.2019.136188

Paoletti, E., and Manning, W. J. (2007). Toward a biologically significant and usable standard for ozone that will also protect plants. Environ. Pollut. 150, 85-95. doi: 10.1016/j.envpol.2007.06.037

Samson, R., Moretti, M., Amorim, J. U., Branquinho, C., Fares, S., Morelli, F., et al. (2019). Towards an integrative approach to evaluate the environmental ecosystem services provided by urban forests. J. For. Res. 30, 1981-1996. doi: 10.1007/s11676-019-00916-x

Shang, B., Feng, Z. Z., Li, P., Yuan, X. Y., Xu, Y. S., and Calatayud, V. (2017). Ozone exposure- and flux-based response relationships with photosynthesis, leaf morphology and biomass in two poplar clones. Sci. Total Enviro. 603-604, 185-195. doi: 10.1016/j.scitotenv.2017.06.083

Sicard, P., Agathokleous, E., Araminiene, V., Carrari, E., Hoshika, Y., De Marco, A., et al. (2018). Should we see urban trees as effective solutions to reduce increasing ozone levels in cities? Environ. Pollut. 243, 163-176. doi: 10.1016/j.envpol.2018.08.049

Sicard, P., De Marco, A., Agathokleous, E., Feng, Z., Xu, X., Paoletti, E., et al. (2020). Amplified ozone pollution in cities during the COVID-19 lockdown. Sci. Total Environ. 735:139542. doi: 10.1016/j.scitotenv.2020.139542

Sicard, P., De Marco, A., Troussier, F., Renou, C., Vas, N., and Paoletti, E. (2013). Decrease in surface ozone concentrations at Mediterranean remote sites and increase in the cities. Atmos. Environ. 79, 705-715. doi: 10.1016/j.atmosenv.2013.07.042

Tuzet, A., Perrier, A., Loubet, B., and Cellier, P. (2011). Modelling ozone deposition fluxes: the relative roles of deposition and detoxification processes. Agric. For. Meteorol. 151, 480-492. doi: 10.1016/j.agrformet.2010.12.004

Yuan, X. Y., Shang, B., Xu, Y. S., Xin, Y., Tian, Y., Feng, Z. Z., et al. (2017). No significant interactions between nitrogen stimulation and ozone inhibition of isoprene emission in Cathay poplar. Sci. Total Environ. 601, 222-229. doi: 10.1016/j.scitotenv.2017.05.138

Zhang, L., Hoshika, Y., Carrari, E., Badea, O., and Paoletti, E. (2018). Ozone risk assessment is affected by nutrient availability: evidence from a simulation experiment under free air controlled exposure (FACE). Environ. Pollut. 328, 812-822. doi: 10.1016/j.envpol.2018.03.102

Zhang, Z., Arshad, A., Zhang, C., Hussain, S., and Li, W. (2020). Unprecedented temporary reduction in global air pollution associated with COVID-19 forced confinement: a continental and city scale analysis. Remote Sens. 12:2420. doi: $10.3390 /$ rs 12152420

Conflict of Interest: The authors declare that the research was conducted in the absence of any commercial or financial relationships that could be construed as a potential conflict of interest.

Copyright (c) 2021 Paoletti, Feng, Fares, Sicard, Agathokleous and De Marco. This is an open-access article distributed under the terms of the Creative Commons Attribution License (CC BY). The use, distribution or reproduction in other forums is permitted, provided the original author(s) and the copyright owner(s) are credited and that the original publication in this journal is cited, in accordance with accepted academic practice. No use, distribution or reproduction is permitted which does not comply with these terms. 